\title{
Quantitative studies on nitrogen metabolism in the bovine rumen
}

\section{The rate of proteolysis of casein and ovalbumin and the release and metabolism of free amino acids}

\author{
By J. L. MANGAN \\ Biochemistry Department, ARC Institute of Animal Physiology, \\ Babraham, Cambridge $C B 2{ }_{4} A T$
}

(Received 8 October 1970-Accepted 27 August 197I)

\begin{abstract}
I. Monozygous twin cattle with permanent rumen fistulas were used to measure the rate of degradation of casein and ovalbumin. One twin was used as a control and the other had protein administered by fistula about $4.75 \mathrm{~h}$ after eating a standard ration.

2. Casein was rapidly degraded with a half-life in the range $5 \cdot 6-2 \mathrm{I} \cdot 5 \mathrm{~min}$, with the formation of peptides, free amino acids and finally ammonia. Up to $43 \%$ of the casein nitrogen was found as ammonia in the rumen fluid. Most of the amino acids present in casein were found in the free state in the rumen fluid to an extent of less than $7 \%$, but valine, leucine, isoleucine and lysine were present as $25,27,21$ and $38 \%$ respectively of the amounts present in the casein administered.

3. When acid-hydrolysed casein was given, ammonia was rapidly formed, the maximum amount found in the rumen being equivalent to $39 \%$ of the casein $\mathrm{N}$. The individual amino acids were rapidly broken down except for valine, leucine, isoleucine and lysine of which synthesis in addition to degradation may occur.

4. Ovalbumin was degraded slowly with a half-life of $175 \mathrm{~min}$, which was reduced to $132 \mathrm{~min}$ by feeding the cattle with ovalbumin for $5 \mathrm{~d}$. Ammonia was produced slowly.

5. When added together the two proteins were degraded in the rumen independently at their own rates.

6. $\delta$-Amino-n-valeric acid was produced in large quantity when casein or casein hydrolysate was degraded in the rumen.
\end{abstract}

Since Syme (1938) demonstrated proteolytic activity in the rumen, it has become well established that the proteins and other nitrogenous constituents of the diet of the ruminant animal undergo extensive transformations in the rumen before passing further down the digestive tract to become available for the nutrition of the animal. Pearson \& Smith (1943), Hoflund, Quin \& Clark (1948) and McDonald (1954) fully confirmed the proteolytic activity of the rumen microflora. Later workers (Bryant \& Burkey, I953; Appleby, 1955; Blackburn \& Hobson, I962; Williams, Davis, Doetsch \& Gutierrez, I961; Abou Akkada \& Howard, 1962) isolated strains of rumen bacteria and protozoa which showed proteolytic activity. McDonald (1948, 1952) found that ammonia was a major end-product of protein degradation in the rumen and recognized its importance in rumen nitrogen metabolism. Subsequent work by El-Shazly (1952), Warner (1956), Lewis (1955) and Annison (1956) showed that protein was broken down to peptides and free amino acids, deamination of the latter producing ammonia in large quantities. Part of the ammonia produced may be resynthesized to microbial protein, but some passes directly through the rumen epithelium, is converted into urea in the liver and largely excreted in the urine (Lewis, Hill \& Annison, 1957). 
Although qualitative studies on $\mathrm{N}$ metabolism in the rumen, often using in vitro techniques, are numerous, quantitative studies on the whole animal have been surprisingly few. McDonald (1954) made use of the properties of zein, i.e. its solubility in ethanol and the absence of lysine in the molecule, to measure its conversion into microbial protein in the rumen of intact sheep. Digesta were collected from the duodenum immediately distal to the pylorus, and analysis gave a minimum value of $40 \%$ conversion. Ely, Little, Woolfolk \& Mitchell (1967) have confirmed the low conversion of zein and shown that the addition of starch does not affect the conversion. Using the same techniques for casein, McDonald \& Hall (1957) found that casein had decreased to a negligible proportion in the duodenal digesta $8-10 \mathrm{~h}$ after feeding and in this time casein equivalent to about $10 \%$ of that given in the diet had passed through the duodenum. It was concluded that $90 \%$ of the casein was degraded and utilized for the synthesis of microbial protein. Weller, Gray \& Pilgrim (1958) used 1,6-diaminopimelic acid and vitamin $B_{12}$ as approximate markers for microbial protein and found that between $63 \%$ and $82 \%$ of the plant $\mathrm{N}$ ingested by sheep was converted into bacterial protein in the rumen. Balch (1957), with cattle, and Gray, Pilgrim \& Weller (1958), with sheep, used the lignin: $\mathrm{N}$ ratio to show that when the $\mathrm{N}$ content of the diet was high $N$ was lost from the rumen but there was no loss or gain when the $N$ content of the food was low. Oyaert \& Bouckaert (1960) used sheep with abomasal fistulas to calculate the gain or loss of $\mathrm{N}$ in the rumen. By the use of duodenal and ileal fistulas, Clarke, Ellinger \& Phillipson (1966) measured the changes in the amino acid composition of the food and digesta during passage down the digestive tract of sheep. By frequent feeding, eight times/d, Hogan \& Weston (1967) obtained 'steady state' conditions in the rumen of sheep. Digesta flow-rates were measured by means of dictary lignin and infused $\left[{ }^{51} \mathrm{Cr}\right]$ ethylenediamine tetraacetic acid, and the total degradation or synthesis of protein was calculated from analysis of diet and digesta. Pilgrim, Gray, Weller \& Belling ( 1970 ) have shown by infusion of $\left[{ }^{15} \mathrm{NH}_{4}\right]_{2} \mathrm{SO}_{4}$ into the rumen of sheep on 'steady state' feeding (hourly) that $76-78 \%$ of bacterial $\mathrm{N}$ and $43-64 \%$ of protozoal $\mathrm{N}$ was derived from ammonia when the sheep was on a low- $\mathrm{N}$ diet. On a high-N diet the values were $62-64 \%$ and $33-41 \%$ respectively. Hume, Moir \& Somers (1970), Hume (1970a,b) and Hume \& Bird (1970), also with steadystate conditions in sheep (twelve feeds/d) and measurement of digesta flow with polyethylene glycol, have studied the production of microbial protein in the rumen as affected by $\mathrm{N}$ intake, the addition of higher volatile fatty acids, the kind of protein and dietary sulphur.

In the present investigation the rate of degradation of soluble proteins in the rumen has been studied in identical twin cattle maintained under defined feeding conditions. The rumen fluid volume was measured in situ at the time of the addition of a known quantity of a protein in solution. The expected concentration of soluble protein in the rumen fluid was then calculated for zero time and the rate of metabolism followed by conventional methods. The protein was added when the flow of digesta from the rumen to the lower digestive tract and the flow of saliva into the rumen were both small, as measured by dilution of PEG and lithium sulphate added as markers. 


\section{EXPERIMENTAL}

\section{Animals}

Two pairs of monozygous twin cattle (Shorthorn ${ }^{*} \times$ Ayrshire$^{\circ}$ steers 1,2 ; Ayrshire ${ }^{*} \times$ Shorthornq steers 3,4$)$ and two dry Jersey cows with permanent rumen fistulas (Harrison, 1961) were used. The animals were allowed to graze at pasture during the summer months and were kept indoors during the winter on a diet of hay and mangolds or kale. Seven days before an experiment began the animals were put into stalls and the steers were given, in two meals, a daily ration of $2.27 \mathrm{~kg}$ chaffed hay, $1 \cdot 36 \mathrm{~kg}$ dried grass meal, $\mathrm{I} \cdot 4 \mathrm{~kg}$ dried beet pulp, $0 \cdot 45 \mathrm{~kg}$ linseed cake and $4.54 \mathrm{~kg}$ kale, cabbage or mangolds. The Jersey cows received the same ration with an additional I kg crushed oats/d. Water was given ad lib., except during the $9 \mathrm{~h}$ experimental periods when it was withheld. The daily ration, with the exclusion of the chaffed hay, was used for the test feed incorporated in the experiments.

\section{Sampling}

Approximately I 1 rumen contents was removed as quickly as possible through the cannula with a $200 \mathrm{ml}$ polyethylene beaker, sampling being directly below the cannula at different levels. The bulked sample thus obtained was spun in a stainless-steel basket centrifuge, with the walls constructed of $30-$ mesh stainless-steel gauze, at $500 \mathrm{~g}$ until fluid ceased to run freely. A small sample ( $100 \mathrm{ml})$ of the crude rumen fluid was taken and the remainder returned to the animal through the cannula. During the sampling the cannula was kept open for the minimum time possible to prevent excessive entry of air into the rumen. The sample for analysis was immediately cooled in an icebath to stop fermentation and centrifuged at $10000 \mathrm{~g}$ for $30 \mathrm{~min}$ at $0^{\circ}$. The clear rumen fluid obtained as the supernatant fraction was essentially free from plant fragments and micro-organisms. Samples were stored at $-20^{\circ}$.

\section{Measurement of rumen fluid volume}

The method of Hydén (1956) using polyethylene glycol, mol. wt 4000 (PEG), and that of Mangan \& Wright (1968) using lithium sulphate were both used.

\section{Experimental procedure}

Monozygous twin steers were fed on the test ration, water being withheld. Samples of rumen fluid were collected immediately before feeding and at timed intervals as shown in Fig. I. The test feed was consumed in the ist hour. At $4.75 \mathrm{~h}$ after the commencement of feeding a solution containing the material under investigation, e.g. Ioo g casein, together with $6.0 \mathrm{~g}$ lithium sulphate monohydrate and $125 \mathrm{~g}$ PEG in 21 glass-distilled water were added to the rumen of one steer through the rumen cannula. At the same time the twin steer was given a similar solution of lithium sulphate and PEG only, and was used as a control. In some experiments a control animal was not used, but other than this the procedure was unchanged. 


\section{$N$ determinations}

Total $\mathrm{N}$ was estimated by the semi-micro-Kjeldahl method of Chibnall, Rees \& Williams (1943) with copper-selenium catalyst. Non-protein $\mathrm{N}$ was determined on deproteinized rumen fluid obtained either by addition of an equal volume of $15 \%$ $(\mathrm{w} / \mathrm{v})$ trichloroacetic acid to clear rumen fluid and centrifugation, or more usually by the picric acid-DOWEX-2 method of Moore \& Stein (1954). Soluble protein N was obtained from the difference between total soluble $\mathrm{N}$ and non-protein N. For ammonia the method of Hill \& Mangan (1964) was used. $\alpha$-Amino $\mathrm{N}$ was measured as carboxyl amino $\mathrm{N}$ by the chloramine-T method of Gerok $\&$ Waller (x956) on rumen fluid deproteinized with picric acid. For peptide amino $\mathrm{N}$ the samples deproteinized with picric acid were hydrolysed with $6 \mathrm{M}-\mathrm{HCl}$ for $24 \mathrm{~h}$ in sealed tubes at $110^{\circ}$, and the increase in carboxyl amino $\mathrm{N}$ was used as a measure of the peptide amino $\mathrm{N}$. To measure casein $\mathrm{N}$, clear rumen fluid $(2 \mathrm{ml})$ was precipitated by ${ }_{5} \%$ trichloroacetic acid $(2 \mathrm{ml})$ and the precipitate was centrifuged and washed by resuspension in $4 \mathrm{ml}$ of $7.5 \%$ trichloroacetic acid and recentrifuging. The protein pellet was digested for 25 min with perchloric acid and phosphate was estimated by the method of Fiske \& Subbarow (1925). Casein N was calculated from the determined $\mathrm{N}$ and $\mathrm{P}$ content of the casein used in the experiments. Recovery of casein $\mathrm{P}$ was $85 \%$ and a correction factor was necessary. The low recovery was probably due to incomplete precipitation or loss of $\mathrm{P}$ from the casein.

\section{Amino acid analysis}

Individual amino acids were determined with an automatic amino acid analyser which was constructed and operated as a two-column system similar to that of Spackman, Stein \& Moore (1958). In the later parts of the work this was changed to a single column $\left(60 \times \mathrm{I}^{\cdot} 5 \mathrm{~cm}\right)$ of sulphonated polystyrene resin eluted with $0.2 \mathrm{M}$-sodium citrate buffer, $\mathrm{pH}_{3.33}$, at $30^{\circ}$ and, after $225 \mathrm{ml}$, was changed to gradient elution at $50^{\circ}$ commencing with $0.2 \mathrm{M}$-sodium citrate buffer, $\mathrm{pH} 4 \cdot 34$, and gradually increasing $\mathrm{pH}$ and salt concentration. Analysis was complete in $20 \mathrm{~h}$. The cyanide-ninhydrin method of Hill \& Mangan (1964) was used. Some analyses were also carried out with a Technicon $\mathrm{NCr}$ analyser (Technicon Instruments Co. Ltd, Basingstoke, Hants.) eluting with a buffer gradient (Wright, I967).

\section{Thin-layer electrophoresis}

Basic amino acids were separated on $20 \times 20 \mathrm{~cm}$ glass plates layered with $0.4 \mathrm{~mm}$ silica gel (Kieselgel H; E. Merck, Darmstadt, Germany) using the Elphor apparatus (Desaga Ltd, Heidelburg, Germany). Immediately before use the plates were sprayed with $0 \cdot 0$ I N-sodium barbiturate buffer, $\mathrm{pH} 9^{\circ} \mathrm{O}$, and electrophoresis was carried out at $400 \mathrm{~V}(20 \mathrm{~V} / \mathrm{cm})$ for $2.5 \mathrm{~h}$. The plates were rapidly dried under infra red lamps, sprayed with ninhydrin $(1 \%, \mathrm{w} / \mathrm{v})$ in acetic acid:butan- $\mathrm{I}-\mathrm{ol}$ :acetone $(5: 40: 50)$ and heated in an oven at $50^{\circ}$ to develop the spots. The basic amino acids gave well-defined spots; neutral and acidic amino acids passed into the buffer in the anode compartment. 


\section{Materials}

Ion exchange resin. Polystyrene cross-linked with $8 \%$ divinyl benzene was prepared in the form of microbeads by dispersion polymerization as described by Hill \& Mangan (1964). After sulphonation with a silver catalyst, a fraction with bead diameter $18 \pm 2 \mu \mathrm{m}$ was isolated by the hydraulic method of Hamilton (1958). This resin was treated exhaustively with I M-nitric acid to remove traces of the silver catalyst. The top of the resin bed in the column was protected from disturbance by a $2 \mathrm{~mm}$ layer of fine asbestos and a closely fitting disc of fine stainless-steel mesh.

Casein. This was 'light, white, soluble', obtained from Hopkins \& Williams Ltd, Chadwell Heath, Essex.

Ovalbumin. This was prepared by the method of Kekwick \& Cannan (1936) and recrystallized with sodium sulphate. The solid was dissolved in a small volume of water and dialysed free from salts. The concentration of protein $\mathrm{N}$ was determined by the Kjeldahl method and the solution was used immediately. Drying or freezing resulted in considerable losses by denaturation.

Casein acid hydrolysate. Casamino acids (Difco Laboratories Inc., Detroit) and casein hydrolysate (acid) (Oxo Limited, London) were both used.

\section{RESULTS}

\section{Expt I. Degradation of casein}

Casein ( $100 \mathrm{~g} \equiv \mathrm{I}_{3} \cdot \mathrm{g} \mathrm{g}$ ) was administered to the rumen of steer I using the monozygous twin steer 2 as control. The results are shown in Fig. I. The semi-log plot of the lithium concentrations found in the rumen fluid is given in Fig. 2, together with the extrapolations to the time of addition. The rumen fluid volumes were calculated from the equation (Hydén, 1956):

$$
C(V+v)=W+C_{0} V,
$$

where $V=$ rumen fluid volume, $v=$ volume of solution added, $W=$ the amount of $\mathrm{Li}$ or PEG added, $C=$ the extrapolated concentration of $\mathrm{Li}$ or PEG, and $\mathrm{C}_{0}=$ the concentration before the addition. The rumen volumes calculated from the $\mathrm{Li}$ concentrations were $59^{\circ} 6$ and $57^{\circ} 1$ for steers $I$ and 2 respectively. The slope of the extrapolation lines showed that dilution of $\mathrm{Li}$ in the rumen due to the combined effects of the secretion of saliva and the passage of rumen fluid down the digestive tract was relatively small and amounted to $16 \%$ in the $3.5 \mathrm{~h}$, during which casein degradation was studied, or $4.6 \%$ per $\mathrm{h}$. Corrections for this small drift have not been made to the results. The plot of $\mathrm{Li}$ concentrations in Fig. 2 shows that, in the samples taken $15 \mathrm{~min}$ after addition to the rumen, the experimentally determined concentrations were appreciably less than the expected values represented by the extrapolated lines, but for the sample taken after 30 min this mixing error had been reduced to less than $10 \%$. During this short period complete mixing of the added solution and the bulk of the rumen fluid had not been reached.

From the calculated rumen fluid volume and the known quantity of casein added 
to the rumen, theoretical concentrations for total soluble $\mathrm{N}$ and soluble protein $\mathrm{N}$ in the rumen fluid were calculated. After the addition of casein (Fig. $\mathrm{r}$ ) the total soluble $\mathrm{N}$ concentration rose to a value in good agreement with the calculated value and then decreased rapidly as the protein was metabolized and utilized by the rumen microorganisms. The soluble protein $\mathrm{N}$, however, reached a maximum concentration that was only $\mathrm{I} 9 \%$ of the expected value, and in $\mathrm{I} h$ all the added protein had disappeared.

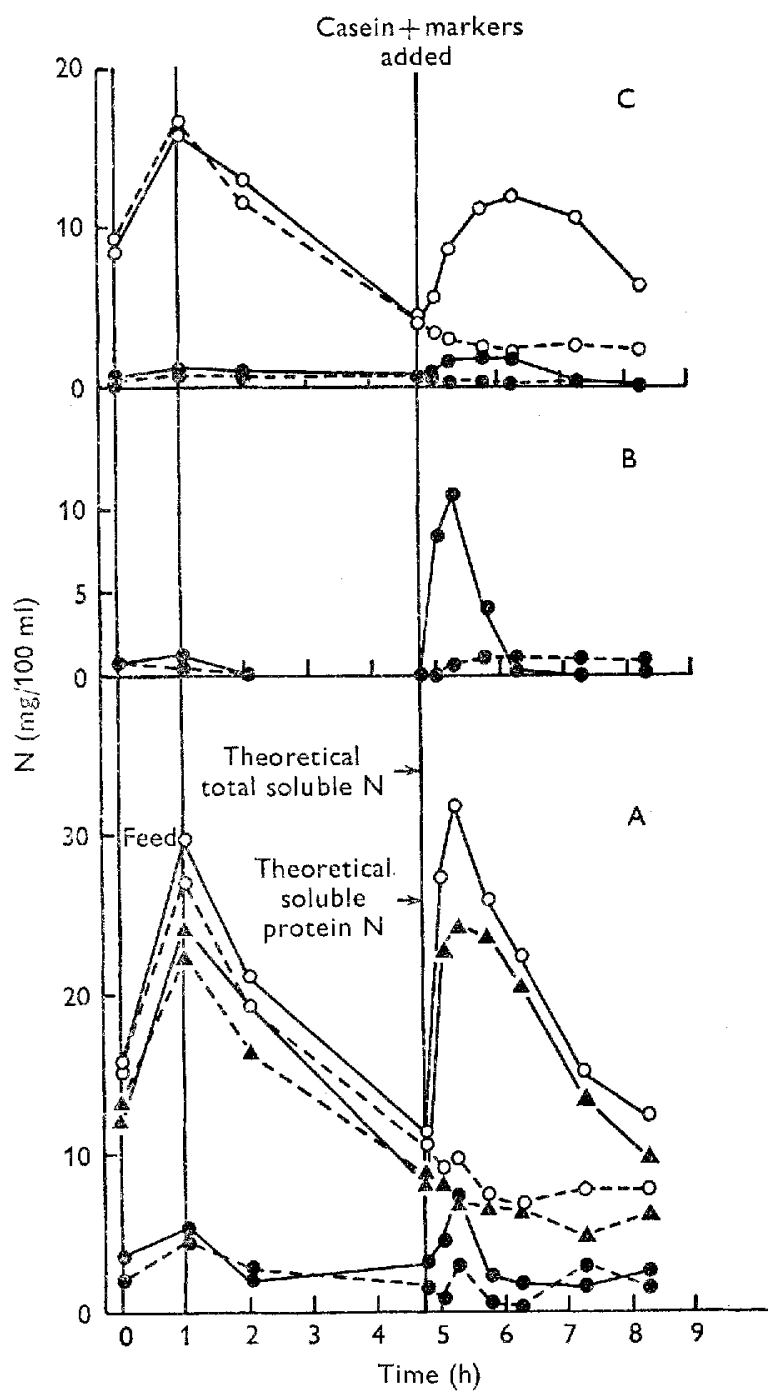

Fig. I. Changes in concentration of various nitrogen fractions in the rumen fluid of a steer after addition of $100 \mathrm{~g}$ casein to the rumen $4.75 \mathrm{~h}$ after a feed. Monozygous twin steer $\mathrm{I}$, casein (roo g) + markers; monozygous twin steer 2, control with markers only. (A) Total soluble $\mathrm{N}$ : $\mathrm{O}-\mathrm{O}$, steer I; $\mathrm{O}--\mathrm{O}$, steer 2 . Non-protein $\mathrm{N}: \mathbf{\Delta}-\boldsymbol{\Lambda}$, steer $\mathrm{I} ; \boldsymbol{\Delta}-\mathbf{\Delta}$, steer $\mathbf{2}$. Soluble protein N: - - steer 2. (C) Ammonia N: $\mathrm{O}-\mathrm{O}$, steer $\mathrm{I} ; \mathrm{O}--\mathrm{O}$, steer 2. Carboxyl amino $\mathrm{N}$ : - - , steer I ; - - o, steer 2. 
This rapid degradation of casein was reflected in a corresponding rise in non-protein $\mathrm{N}$. This non-protein $\mathrm{N}$ consisted mainly of peptides and ammonia and to a less extent free amino acids (Fig. r). Peptides reached their maximum concentration $30 \mathrm{~min}$ after the addition of casein and thereafter rapidly disappeared from the rumen fluid; the maximum peptide amino $\mathrm{N}$ was equivalent to $49.7 \%$ of the total $\mathrm{N}$ of the added

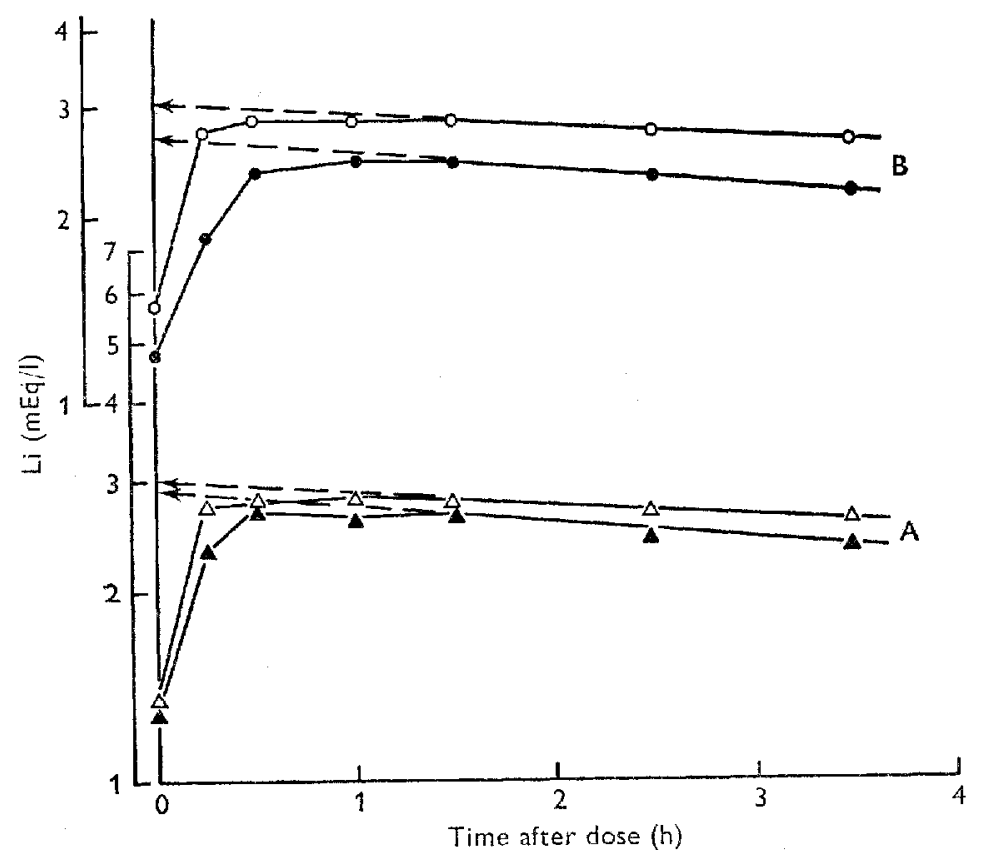

Fig. 2. Concentration of lithium in rumen fluid in relation to time after administration of lithium sulphate to the rumen. (A) Casein, Expt I; $\mathbf{A}-\mathbf{A}$, monozygous twin steer 1 ; $\triangle-\Delta$, monozygous twin steer 2. (B) Casein hydrolysate, Expt $2 ;-\longrightarrow$, monozygous twin steer $\mathrm{I} ; \mathrm{O}-\mathrm{O}$, monozygous twin steer 2 .
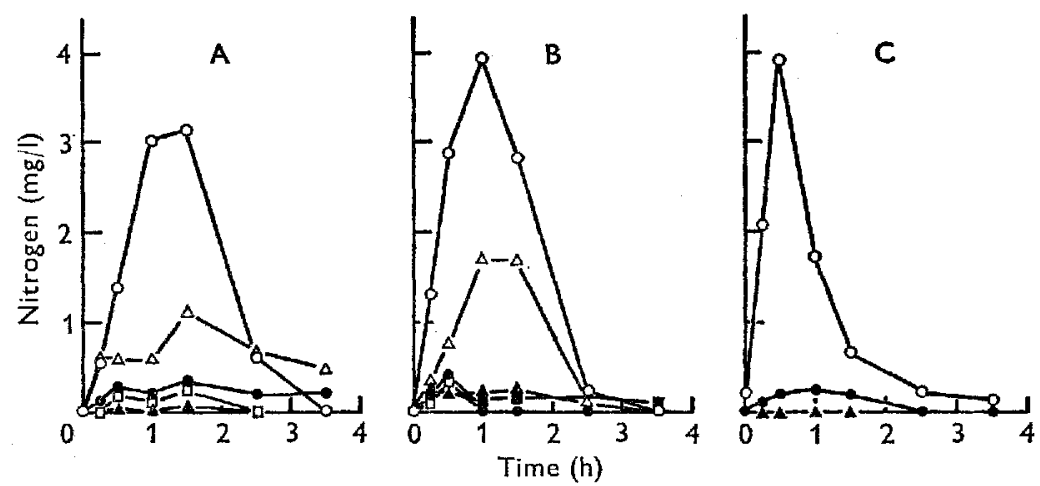

Fig. 3. Concentration of individual free amino acids in rumen fluid in relation to time after addition of casein $(100 \mathrm{~g})$ to the rumen of a steer. (A) $\mathrm{O}-\mathrm{O}, \mathrm{Val} ; \Delta-\triangle$, Glu;

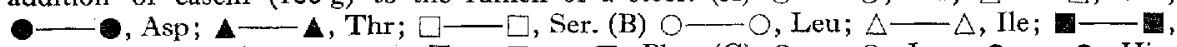
Gly; $\triangle-\Delta$, Ala; -0 , Tyr; $\square-\square$, Phe. (C) $\bigcirc-O$, Lys; $-\bigcirc$. His; $\Delta-\mathbf{A}, \mathrm{Arg}$. 


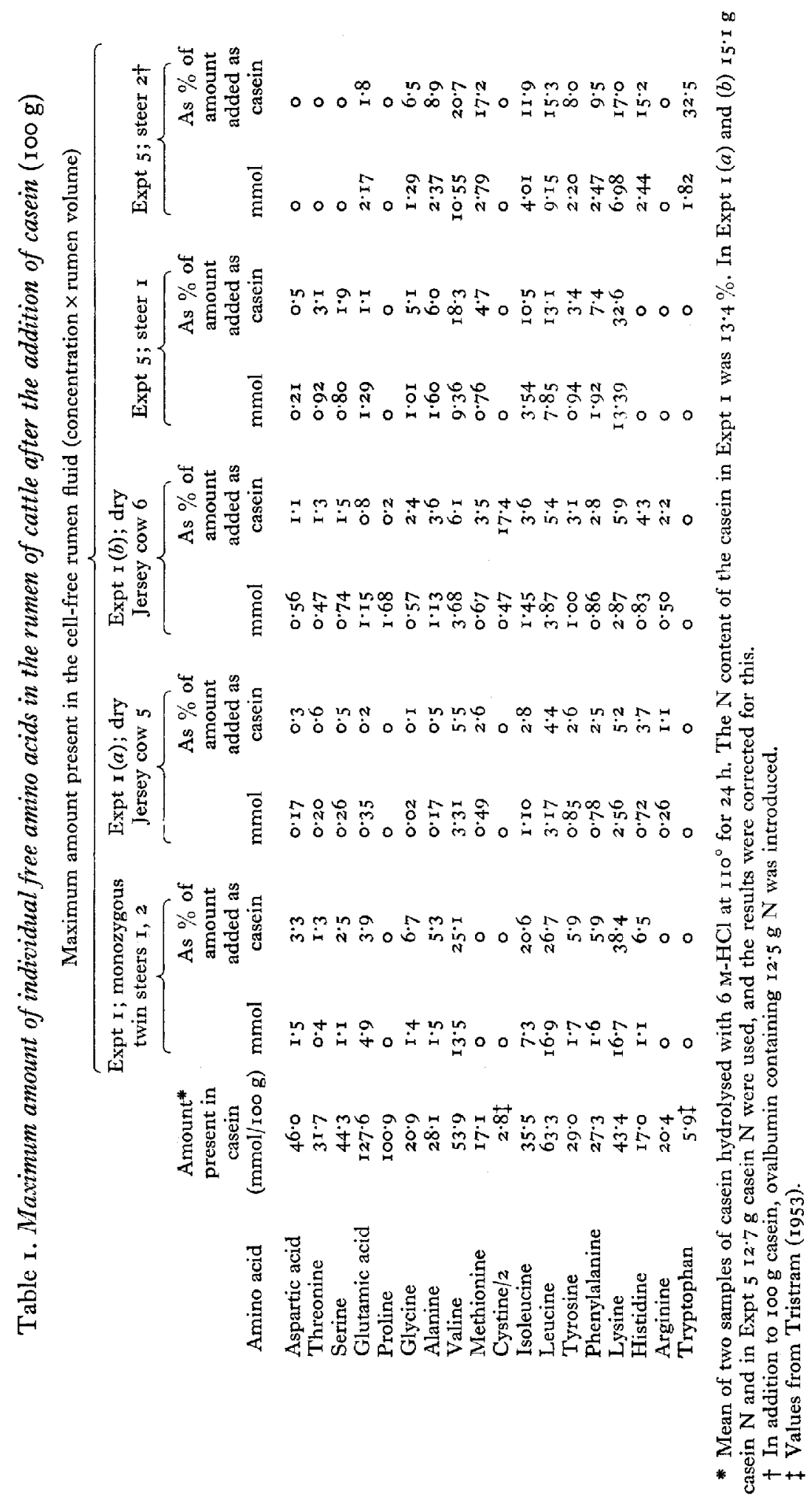


casein. From the amino acid composition of casein, only $74.7 \%$ of the total $\mathrm{N}$ can be released as $\alpha$-amino $\mathrm{N}$ and by use of this factor it was calculated that the concentration of peptide total $\mathrm{N}$ reached a maximum equivalent to $66.5 \%$ of the $\mathrm{N}$ added as casein.

Ammonia was produced rapidly (Fig. I) from casein, but with a distinct time lag following the formation of peptides, the highest concentration occurring in the rumen fluid when peptide $\mathrm{N}$ had decreased to zero. The ammonia curve for the control steer showed that ammonia produced during the test feed had almost disappeared and had reached a fairly stable equilibrium value. The difference between the two curves is

Table 2. Maximum amounts (concentrations $\times$ rumen volume) of ammonia, a-amino nitrogen and peptide nitrogen present in the rumen of cattle after the introduction of $\mathrm{I} 0 \mathrm{~g}$ casein

\begin{tabular}{|c|c|c|c|c|c|c|}
\hline & $\begin{array}{c}\text { Expt I: } \\
\text { mono- } \\
\text { zygous } \\
\text { twin } \\
\text { steers } \\
I, 2^{*}\end{array}$ & $\begin{array}{l}\text { Expt I }(c): \\
\text { mono- } \\
\text { zygous } \\
\text { twin } \\
\text { steers } \\
3,4^{*}\end{array}$ & $\begin{array}{c}\text { Expt } \mathrm{I}(d): \\
\text { mono- } \\
\text { zygous } \\
\text { twin } \\
\text { steers } \\
x, 2 \dagger\end{array}$ & $\begin{array}{l}\text { Expt 5: } \\
\text { steer i }\end{array}$ & $\begin{array}{c}\text { Expt I }(a): \\
\text { dry } \\
\text { Jersey } \\
\text { cow 5t }\end{array}$ & $\begin{array}{c}\text { Expt I }(b): \\
\text { dry } \\
\text { Jersey } \\
\text { cow } 6 \dagger\end{array}$ \\
\hline Rumen volume (1) & $59.6 f$ & $57 \cdot 2 \ddagger$ & $\left\{\begin{array}{l}49^{\circ} 5 \\
5 \mathrm{x} \cdot 5\end{array}\right\}$ & 64.5 & $28 \cdot 7$ & $23 \cdot 9$ \\
\hline Casein $\mathrm{N}$ given $(\mathrm{g})$ & 13.4 & $13 \cdot 2$ & $14 \cdot 2$ & $12 \cdot 7$ & 15.1 & I5.I \\
\hline $\begin{array}{l}\text { Time of administration (h } \\
\text { after beginning of test feed) }\end{array}$ & 4.75 & $4 \cdot 66$ & $4 \cdot 75$ & $4 \cdot 75$ & $4 \cdot 80$ & $4 \cdot 80$ \\
\hline Half-life of protein (min) & $16 \cdot 9$ & I3. I & $\left\{\begin{array}{l}5.6 \\
5.6\end{array}\right\}$ & $18 \cdot 0$ & $14 \cdot 5$ & $2 \mathrm{I} \cdot 5$ \\
\hline $\begin{array}{l}\text { Maximum ammonia } N(\% \text { of } \\
\text { casein } N \text { added) }\end{array}$ & $43 \cdot 0$ & $41 \cdot 4$ & $\left\{\begin{array}{l}3 \mathrm{I} \cdot 41 \\
34 \cdot 0\}\end{array}\right.$ & $44^{\cdot} \mathrm{I}$ & $19 \cdot 2 \S$ & ז8*2\$ \\
\hline $\begin{array}{l}\text { Maximum peptide } N(\% \text { of } \\
\text { casein } N \text { added) }\end{array}$ & $66 \cdot 5$ & - & - & $50 \cdot 6$ & $43 \cdot 1 \S$ & $47 \cdot 6 \S$ \\
\hline $\begin{array}{l}\text { Maximum } \alpha \text {-amino } N \text { ( } \% \text { of } \\
\text { casein } N \text { added) }\end{array}$ & $7 \cdot 2$ & 一 & - & $7 \cdot 9$ & $2 \cdot 0 \S$ & $2 \cdot 6 \S$ \\
\hline
\end{tabular}

a measure of ammonia produced from casein and the greatest value was equivalent to $43 \%$ of the casein $\mathrm{N}$ added to the rumen. This does not represent all the ammonia produced since some is converted into microbial protein. Moreover, as the ammonia concentration increases, the rate of absorption from the rumen may increase compared with that in the control animal.

Administration of casein produced a small but significant increase in the carboxyl amino $\mathrm{N}$, representing the release of free amino acids into the rumen fluid. The time sequence of the appearance of the nitrogenous fractions indicated that casein was broken down in the normal way to peptides, then amino acids and finally ammonia, which was metabolized and absorbed relatively slowly and in the later stages was the only significant soluble product of casein degradation.

The carboxyl amino $\mathrm{N}$ peak was small and represented a maximum of only $7 \cdot 2 \%$ of the original casein N. Despite the heterogeneous nature of the bacterial and protozoal 
population in the rumen, measurable differences in behaviour of individual amino acids emerged, as are shown in Fig. 3 . All the amino acids originally present in the casein except arginine, cystine, methionine, proline and tryptophan were released rapidly into the rumen fluid and were detected within $15 \mathrm{~min}$ of addition of casein. Aspartic acid, glutamic acid, serine, thrconine, glycine, alanine, tyrosine, phenylalanine and histidine were liberated only in small amounts, maximum concentrations being about $7 \%$ or less of the amount originally present in the casein (Table 1 ). Glutamic acid is the most abundant amino acid residue in casein, but the peak concentration was equivalent to only $3.2 \%$ of the amount present in the casein. Of the amino acids not detected in the rumen fluid, cystine and tryptophan were present only in small amounts in casein, and proline gives a low colour yield with ninhydrin, but arginine and methionine were present in casein in amounts similar to those of glycine, alanine, and histidine, which were identified. Hence, it must be assumed that arginine and methionine were metabolized very rapidly. In contrast to the rapidly metabolized amino acids, valine, leucine, isoleucine and lysine rapidly accumulated to a relatively high concentration in the rumen fluid. The peak concentrations (Table I) were equivalent to $25 \%, 27 \%, 21 \%$ and $38 \%$ respectively of the quantity originally present in the added casein. The rapidly descending arm of the concentration curves for these four amino acids indicated that the accumulation in the rumen fluid occurred in spite of the relatively fast rates of metabolism.

The results of several other experiments are given in Table $x$ and confirm that these effects occur with other animals. In Expts $\mathrm{I}(a)$ and $(b)$ the supplementation of the diet of the Jersey cows with $\mathrm{I}$ kg crushed oats/d was associated with a depression in the concentration of ammonia and total free amino acids in the rumen (Table 2), but the concentrations of valine, leucine, isoleucine and lysine were again higher than those of other amino acids. The relatively high concentration of cystine in Expt $x(b)$ cannot be explained. In Expt 5, steer 2 had roo g ovalbumin in addition to $100 \mathrm{~g}$ casein. The concentrations of these four amino acids retained their special position but, calculated. as a percentage of the casein added, tryptophan, histidine and methionine were also present in large amounts, probably enhanced by a contribution from the degradation of ovalbumin.

Table 2 shows the results of several experiments with a second pair of monozygous twin steers and two Jersey cows. The degradation of casein followed the same general pattern described above.

\section{Expt 2. Metabolism of casein amino acids}

Casein amino acids ( $170 \mathrm{~g} \equiv \mathrm{I}_{4} \times \mathrm{g} \mathrm{N}$ ) equivalent to $100 \mathrm{~g}$ casein were added to the rumen of steer $\mathrm{I}$ under conditions described under experimental procedure, using steer 2 as control. During the test feeding and for $3.75 \mathrm{~h}$ after, the analytical results (Fig. 4) for the pair of twins were in good agreement. After the addition of the casein amino acids the concentrations of total soluble $\mathrm{N}$, non-protein $\mathrm{N}$ and carboxyl amino $\mathrm{N}$ increased to values which were in line with theoretical values calculated from the rumen volumes $\left(60^{\circ} 3\right.$ and $55^{\circ} 71$ respectively by the $\mathrm{Li}$ method) and the quantity of hydrolysed casein. The control steer had reached a reasonably steady equilibrium 
value for all constituents analysed. After the peak value was reached the total soluble $\mathrm{N}$ decreased rapidly, indicating a rapid uptake of $\mathrm{N}$ by the rumen organisms and absorption through the rumen epithelium, the rate being approximately the same as with intact casein. The disappearance of free amino acids from the rumen fluid resulted in a sharp rise in free ammonia concentrations, the peak being equivalent to $39 \%$ of the

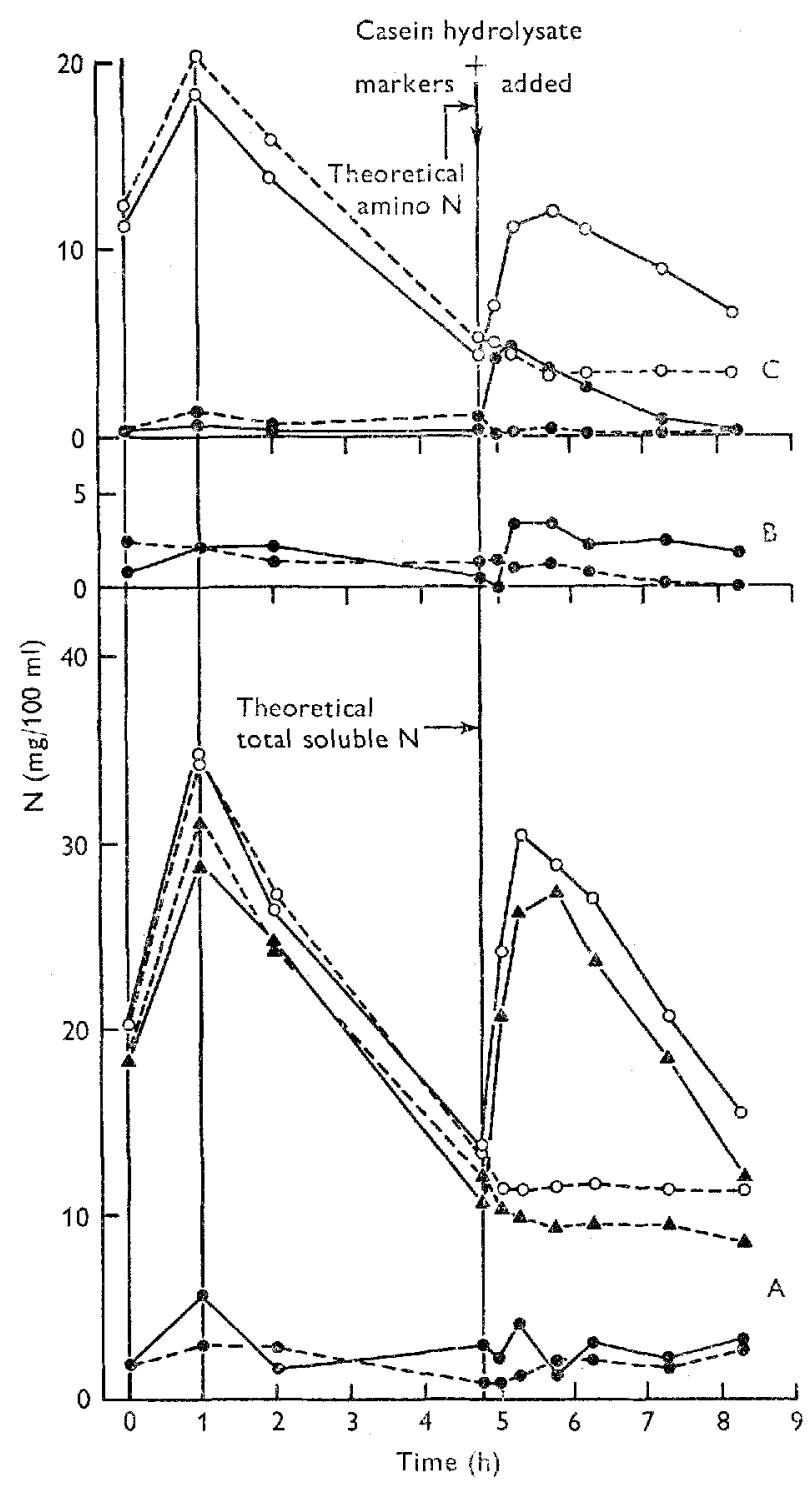

Fig. 4. Changes in concentration of various nitrogen fractions in rumen fluid after the addition of $100 \mathrm{~g}$ acid-hydrolysed casein to the rumen, $4.75 \mathrm{~h}$ after a feed. Monozygous twin steer I, casein amino acids + markers; monozygous twin steer 2 , control with markers only. (A) Total soluble $\mathrm{N}: \mathrm{O}-\mathrm{O}$, steer $\mathrm{I} ; \mathrm{O}--\mathrm{O}$, steer 2 . Non-protein $\mathrm{N}: \boldsymbol{\Lambda}-\boldsymbol{\Lambda}$, steer $\mathbf{I} ; \boldsymbol{\Delta}--\boldsymbol{\Lambda}$, steer 2. Soluble protein N: - - steer I; - - steer 2. (B) Peptide amino N: - steer I; - steer 2. (C) Ammonia N: $\mathrm{O}-\mathrm{O}$, steer $\mathrm{I} ; \mathrm{O}-\mathrm{O}$, steer 2. Carboxyl amino $\mathrm{N}:-1-\mathrm{O}$, steer $\mathrm{I} ; 0-\mathrm{O}$, steer 2. 
total $\mathrm{N}$ added to the rumen, a proportion very similar to that produced by intact casein. The casein hydrolysate used contained a small amount of inert peptide which was not metabolized by the rumen micro-organisms (Fig. 4), and was probably a resistant peptide produced by transformations during acid hydrolysis.

Individual amino acids were very rapidly metabolized (Fig. 5). The concentrations at $\mathrm{o}$ are values calculated from the amino acid composition. Glutamic acid, the most abundant residue in casein, had almost completely disappeared in the first $30 \mathrm{~min}$. Aspartic acid, serine, threonine, glycine, alanine, methionine, tyrosine, phenylalanine and histidine behaved similarly. As with intact casein, cystine and arginine could not
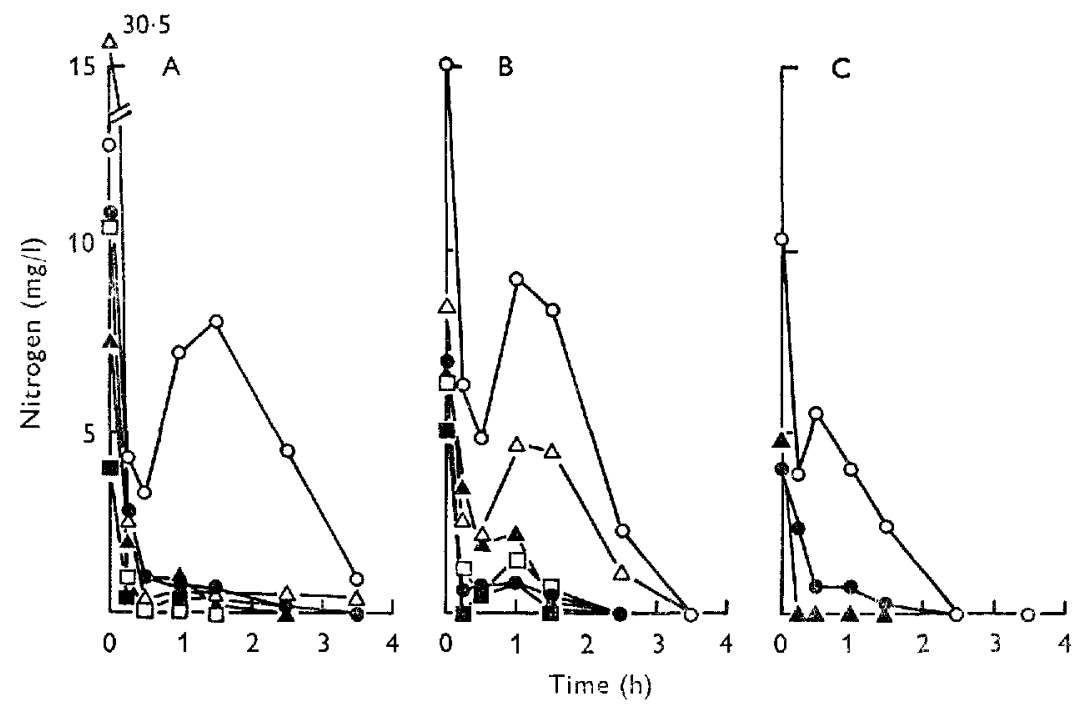

Fig. 5. Concentration of individual free amino acids in rumen fluid of steers in relation to time after addition of hydrolysed casein to the rumen. (A) $\mathrm{O}-\mathrm{O}, \mathrm{Val}$; $-\mathrm{O}$, Asp;

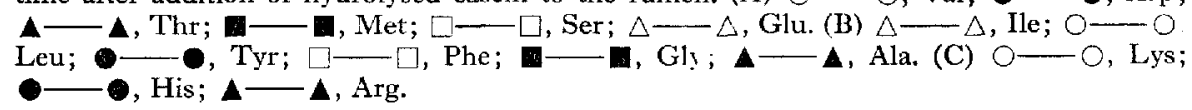

be detected in the rumen fluid ${ }_{5}$ min after the addition of casein hydrolysate to the rumen and appeared to be extremely rapidly metabolized. Valine, leucine, isoleucine and lysine again formed a distinct group. The rapidly descending parts of the concentration curves, indicated that these four amino acids were rapidly metabolized, but synthesis from the degradation products of other amino acids occurring at the same time could result in the sigmoid concentration curves shown in Fig. 5. This could also be partly due to inadequate mixing of the casein hydrolysate in the rumen. The quantities of the individual amino acids were therefore calculated per $\mathrm{mEq} \mathrm{Li}^{+}$added with the casein hydrolysate as a marker. In Expt 2 (Table 3) most of the amino acids showed a rapid and continuous fall in their concentration relative to $\mathrm{Li}^{+}$with no indication of synthesis. Valine, leucine and isoleucine showed a fall followed by a distinct rise in their ratio. Lysine showed a continuous but very slow decrease. In Expt 2(a) (Table 3) the same pair of identical twins were given a similar quantity 
Vol. 27

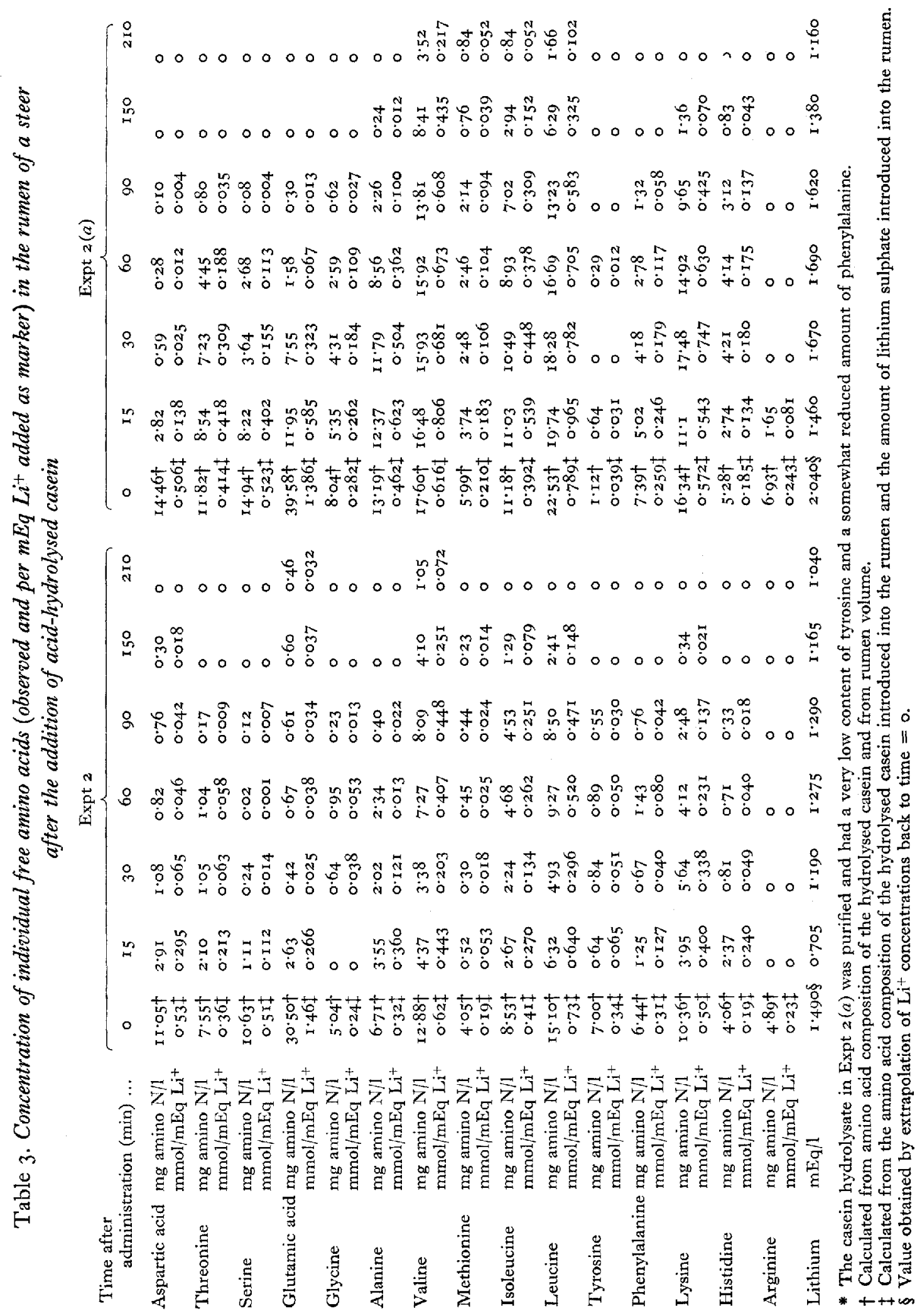


$(14.9 \mathrm{~g} \mathrm{~N})$ of purified casein hydrolysate. Most of the amino acids again showed a continuous decrease in their ratio to $\mathrm{Li}^{+}$, but valine, leucine, isoleucine and lysine showed increases in their ratios above the initial values calculated from the composition of the casein hydrolysate and the amount of lithium sulphate added to the rumen. These results suggest that these four amino acids may be synthesized in the rumen. Histidine and alanine may also be synthesized to a lesser extent.

\section{Expt 3. Rate of metabolism of casein and casein hydrolysate}

The rate of disappearance of the total soluble $\mathrm{N}$ from the rumen fluid when pairs of twin cattle were given casein and an equivalent amount of acid-hydrolysed casein direct into the rumen is shown for three experiments in Fig. 6 . The conditions for

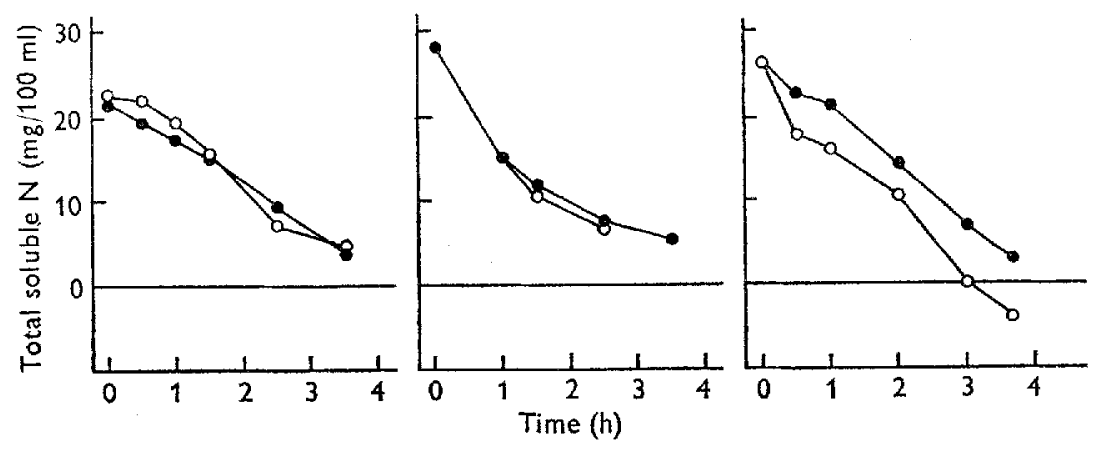

Fig. 6. Comparison of the rate of disappearance of casein nitrogen $(\mathrm{O}-\mathrm{O}$ ) and casein hydrolysate $\mathrm{N}(-\infty)$ ) in three experiments using pairs of monozygous twin cattle.

the experiments and the measurement of rumen volumes were the same as described above. Within experimental error the $\mathrm{N}$ of intact casein was either taken up by the rumen micro-organisms or absorbed by the rumen epithelium as fast as that of acidhydrolysed casein. The proteolytic step was very rapid and under the conditions of these experiments was apparently not rate-limiting in the utilization of the protein $\mathrm{N}$.

\section{Expt 4. Degradation of ovalbumin}

Recrystallized ovalbumin ( $16 \cdot 2 \mathrm{~g} \mathrm{~N}$; approx. $100 \mathrm{~g}$ protein) was administered to steer $\mathrm{I}$ by rumen fistula and its degradation studied. Steer 2 was the control animal. The analytical results (Fig. 7) show that the pair of animals was behaving in close agreement and by the time the protein solution was added to the rumen all the nitrogenous constituents had reached a fairly steady state. The rumen fluid volumes for the experimental and control animals were $5^{2} \cdot 3$ and $49^{\circ} 61$ measured by PEG and $54^{*} 4$ and 49.91 measured by $\mathrm{Li}$ respectively. After ovalbumin was added to the rumen the total soluble $\mathrm{N}$ rose to the expected value and then decreased slowly. In marked contrast to the behaviour of casein in the rumen, the soluble protein $\mathrm{N}$ rose almost to the theoretical value and thereafter decreased slowly, indicating a slow rate of proteolysis. This was confirmed by a gradual increase in the non-protein N (Fig. 7). Peptides and free amino acids appeared only in small amounts. In contrast to the casein-treated 


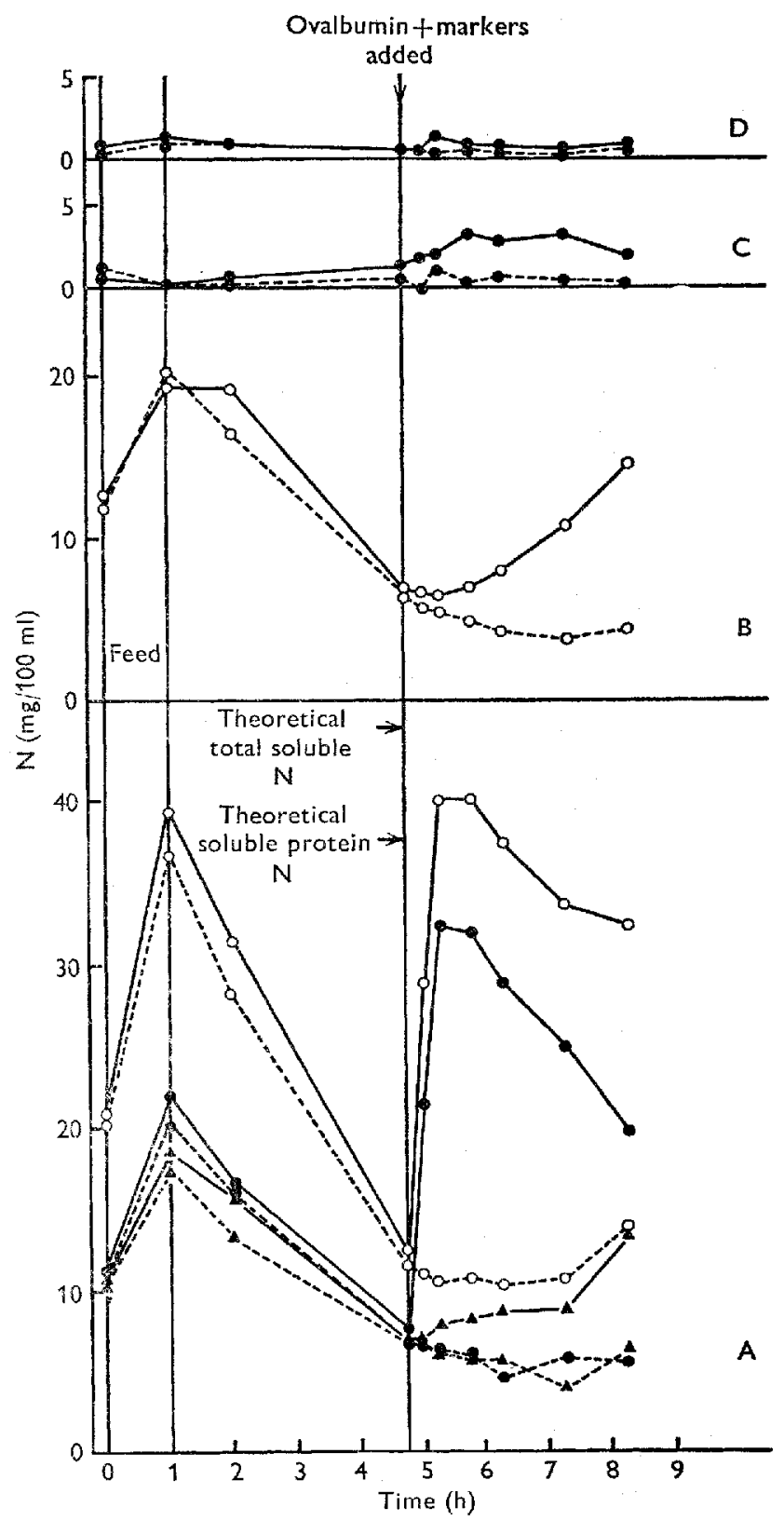

Fig. 7. Changes in concentration of various nitrogen fractions in rumen fluid after addition of ovalbumin to the rumen, $4 \cdot 75 \mathrm{~h}$ after a feed. Monozygous twin steer 1 , ovalbumin (roo g) + markers; monozygous twin steer 2, control with markers only. (A) Total soluble $\mathrm{N}: \mathrm{O}-\mathrm{O}$, steer I; $\mathrm{O}-\mathrm{O}$, steer 2. Non-protein $\mathrm{N}: \mathbf{A}-\mathbf{A}$, steer $\mathrm{I} ; \boldsymbol{\Delta}-\mathbf{\Delta}$, steer 2. Soluble protein N: - steer I; - - steer z. (B) Ammonia N: $0-0$, steer $\mathrm{r} ; 0--0$, steer 2. (C) Peptide amino N: - steer I; - - steer 2. (D) Carboxyl amino N: - , steer I; $--\infty$, steer 2. 
animal, ammonia concentration increased slowly, but $3.5 \mathrm{~h}$ after administration of ovalbumin the amount of ammonia present in the rumen measured by the difference between concentrations in test and control animals was equivalent to $35.2 \%$ of the total $\mathrm{N}$ added to the rumen. This is similar to the maximum amount of ammonia present in the rumen after casein administration (Table 2).

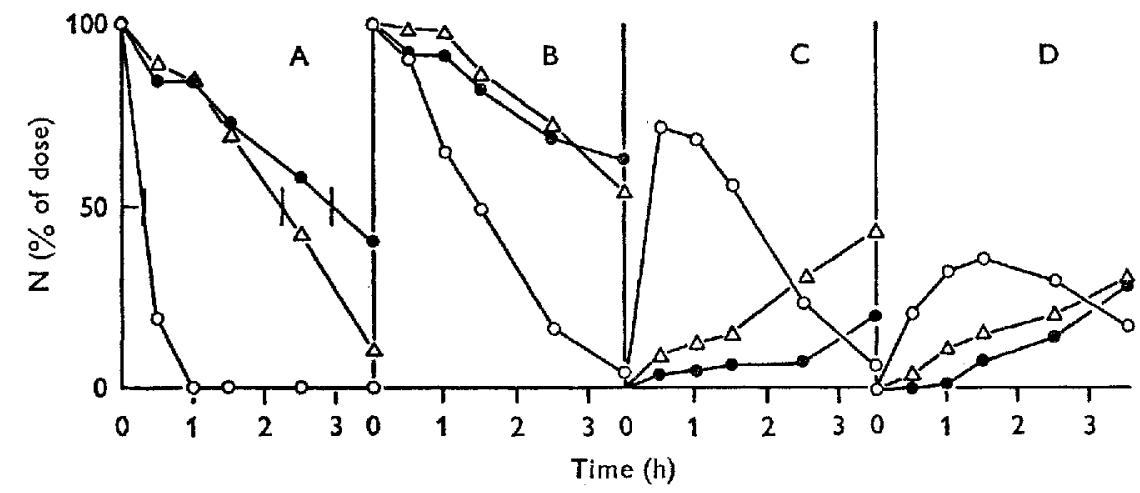

Fig. 8. Comparison of changes in various nitrogen fractions in rumen fluid of steers (as \% of dose) after addition of casein or ovalbumin to the rumen. $\mathrm{O}-\mathrm{O}$, casein; -1 , ovalbumin; $\triangle \longrightarrow \triangle$, ovalbumin after $5 \mathrm{~d}$ adaptation. (A) Soluble protein $N$; (B) total soluble $N$; (C) non-protein N; (D) ammonia $\mathrm{N}$.

Intraruminal treatment of the cattle with Ioog ovalbumin/d for $5 \mathrm{~d}$, followed by repetition of the above experiment, caused only a small increase in the rate of proteolysis of ovalbumin, the results being very similar to those in Fig. 7. In Fig. 8 the results for ovalbumin after $5 \mathrm{~d}$ adaptation, expressed as $\%$ of protein $\mathrm{N}$ in the dose, are compared with those for casein and ovalbumin without pretreatment. The approximate times required for half the added protein to be broken down were $19.5 \mathrm{~min}$ for casein, $175 \mathrm{~min}$ for ovalbumin and $\mathrm{I} 32 \mathrm{~min}$ for ovalbumin after $5 \mathrm{~d}$ of treatment. The rate of disappearance of total soluble $\mathrm{N}$, representing the uptake of nitrogenous compounds by the rumen micro-organisms, and the rate of formation of degradation products demonstrate that ovalbumin is metabolized in the rumen at a much slower rate than casein. Pretreatment, which is not required for the rapid degradation of casein, did not greatly induce adaptation to ovalbumin degradation.

\section{Expt 5. Degradation of a mixture of ovalbumin and casein}

The apparent inability of the rumen micro-organisms to metabolize ovalbumin rapidly could possibly have been due to the presence of inhibitors in the ovalbumin preparations or to the binding of proteolytic sites. In an experiment using the same pair of identical twin cattle as in Expt 4, one animal was given $100 \mathrm{~g}$ casein (12.7 g N) and the other $100 \mathrm{~g}$ casein $(12.7 \mathrm{~g} \mathrm{~N})$ and $100 \mathrm{~g}$ ovalbumin $(12 \cdot 5 \mathrm{~g} \mathrm{~N})$. Rumen volumes were estimated as $60^{\circ} 5$ and 58.61 by $\mathrm{Li}$ and 68.5 and 64.11 by PEG. Mean values of 64.51 and $6 \mathrm{r}_{4} \cdot 1$ were used in the calculations. The results for the test feed showed (Fig. 9) that the twins were behaving in close agreement. After the administration of the protein solutions, the total soluble $\mathrm{N}$ in the rumen fluid of both animals rose to 


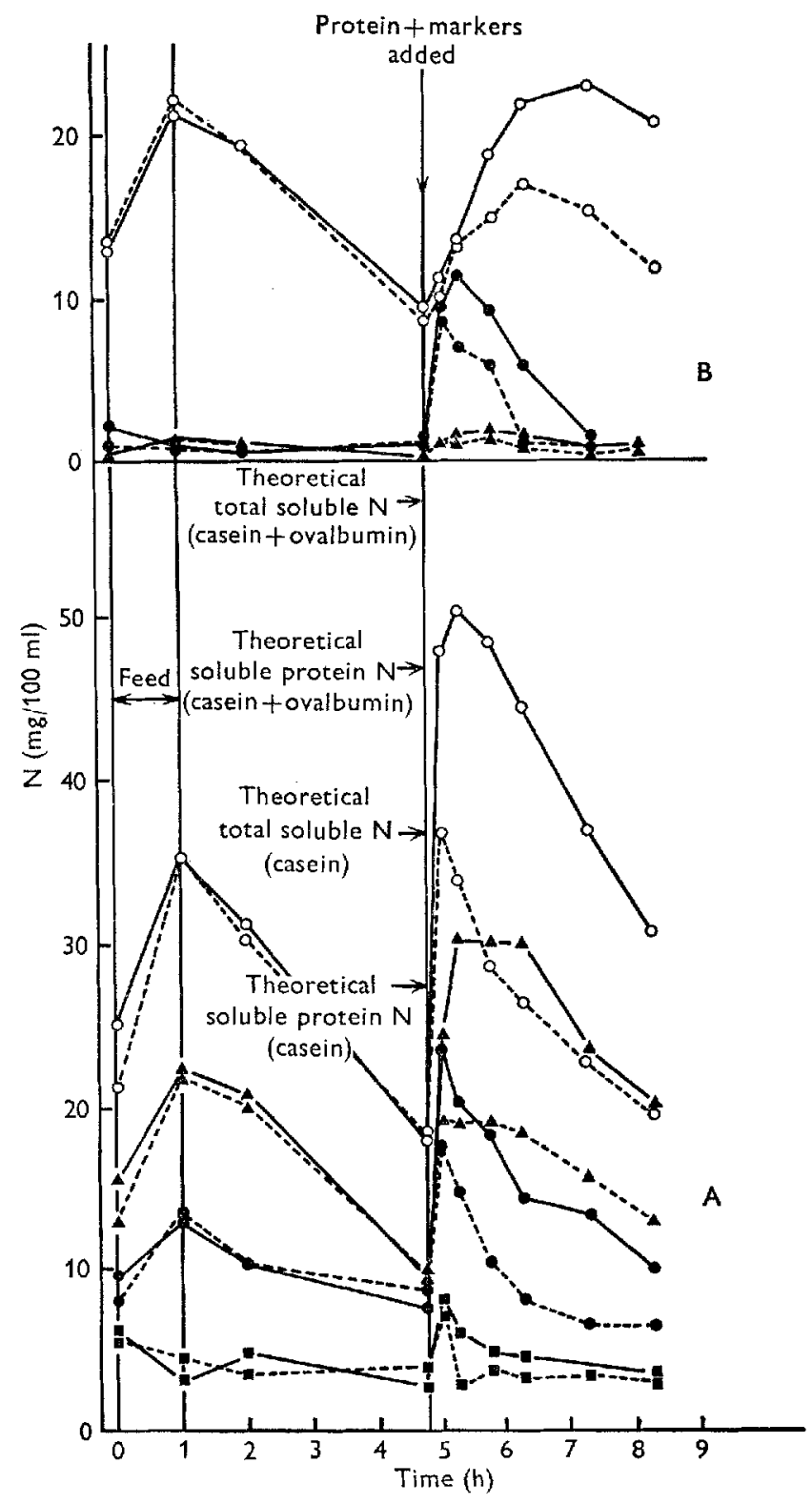

Fig. 9. Changes in concentration of nitrogen fractions in rumen fluid after addition of a mixture of casein and ovalbumin to the rumen, $4.75 \mathrm{~h}$ after a feed. Monozygous twin steer I, casein ( $100 \mathrm{~g})+$ markers; monozygous twin steer 2 , casein ( $100 \mathrm{~g})+$ ovalbumin $(100 \mathrm{~g})+$ markers. (A) Total soluble $\mathrm{N}: \mathrm{O}--\mathrm{O}$, steer $\mathrm{r} ; \mathrm{O}-\mathrm{O}$, steer 2. Non-protein $\mathrm{N}: \mathbf{A}-\mathbf{A}$, steer $\mathrm{r}$; $\Delta-\mathbf{A}$, steer 2. Soluble protein $\mathrm{N}: \mathbf{-}-\mathbf{O}_{1}$, steer $\mathrm{I} ; \mathbf{-}-\mathbf{O}$, steer 2. Casein phosphate $\mathrm{N}: \mathbf{\square}-\mathbf{\square}$, steer I; $\mathbf{D}-\mathbf{Z}$, steer 2. (B) Ammonia $\mathrm{N}: \mathrm{O}-\mathrm{O}$, steer I; $\mathrm{O}-\mathrm{O}$, steer 2. Peptide amino $\mathrm{N}: \mathrm{O}_{-}-\mathrm{O}$, steer $\mathrm{I} ; \mathrm{O}_{-}$, steer 2. Carboxyl amino $\mathrm{N}: \boldsymbol{\Lambda}--\boldsymbol{\Lambda}$, steer I; $\mathbf{A}-\mathbf{A}$, steer $\mathbf{2}$. 
expected values calculated from the rumen fluid volumes and thereafter decreased rapidly, casein at a somewhat faster rate than casein +ovalbumin. In the casein-treated animal, soluble protein $\mathrm{N}$ rose in the first I $_{5} \min$ to a value $56 \%$ of the theoretical concentration and then rapidly decreased, virtually all the protein being broken down in the Ist hour. At first casein + ovalbumin was also rapidly hydrolysed, but after $\mathrm{I} \mathrm{h}$ this initial rate decreased quite sharply and proteolysis then proceeded at a much slower rate, indicating that the two proteins in the mixture were hydrolysed at different rates. In Fig. Io the results for soluble protein $\mathrm{N}$ are expressed as a semi-logarithmic

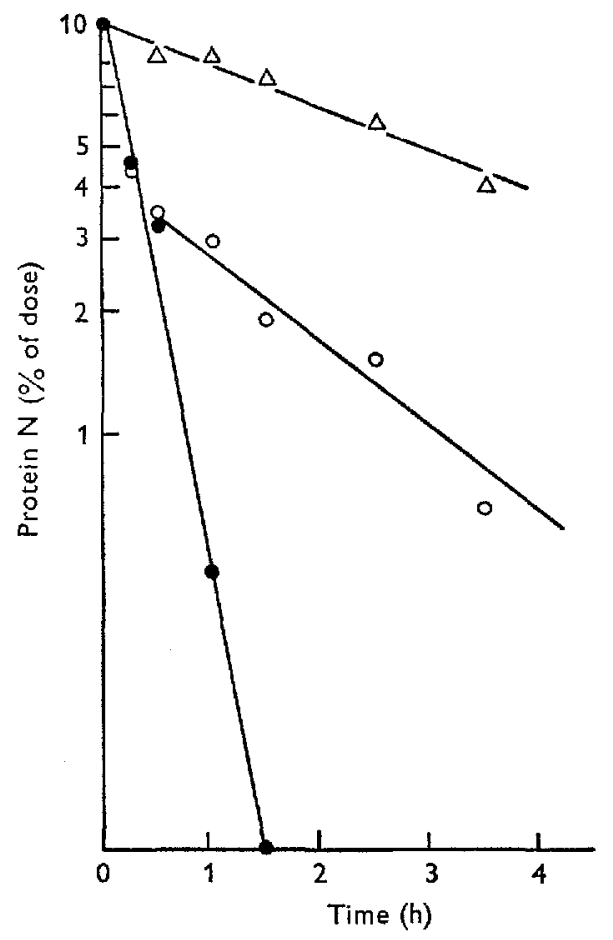

Fig. 10. Comparison of changes in soluble protein nitrogen (as \% of dose) in rumen fluid after the addition of casein, ovalbumin and casein +ovalbumin to the rumen, $475 \mathrm{~h}$ after a feed. Rate of degradation of casein, - o ovalbumin, $\triangle-\triangle$; and casein + ovalbumin, $Q-O$. The experiment for each protein was made under similar conditions and with the same pair of identical twin cattle, one of which acted as a control in each experiment.

plot with the inclusion of the breakdown values for ovalbumin alone obtained in a previous experiment. The proteolysis of casein and ovalbumin separately gave straight-line relationships with time with very different slopes. The plot for the mixture of the two proteins can be readily separated into two components, a fast one identical to casein within experimental error, followed by a slow one very similar to ovalbumin. The formation of peptides, free amino acids and ammonia from the mixture as compared with casein alone (Fig. 9) confirms that the degradation of casein was not inhibited by the presence of an equal amount of ovalbumin, and there was an increment in the amounts of degradation products due to the breakdown of ovalbumin. The measurement of casein $\mathrm{N}$ similarly showed that intact casein was rapidly degraded 
in both animals and appeared only as small transient peaks. There was no significant difference due to ovalbumin.

\section{The formation of $\delta$-amino-n-valeric acid}

Of the amino compounds present in the rumen fluid in these experiments, the major peaks of leucine, isoleucine, valine and lysine and the minor peaks of other constituent amino acids of proteins have already been described. In addition to these there is (a) an unknown compound which chromatographs in the position of $\alpha$-amino-n-butyric acid, $(b)$ methylamine, the formation and behaviour of which has been described by Hill \& Mangan (1964), and (c) a major peak of $\delta$-amino-n-valeric acid.

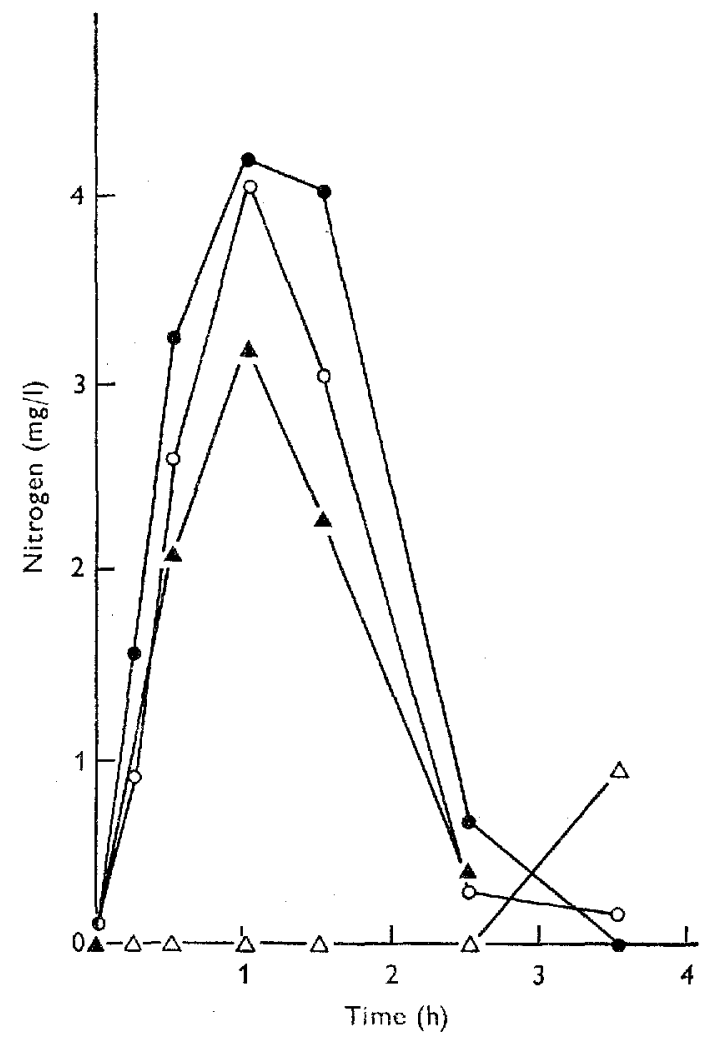

Fig. I I. Formation of $\delta$-amino-n-valeric acid in the rumen of steers after the addition of casein (I00 g), $\bigcirc-O$; hydrolysed casein (100 g), - ; ovalbumin (I00 g), $\triangle-\triangle$; and casein (100 g) +ovalbumin ( $100 \mathrm{~g}), \mathbf{A}-\mathbf{\Lambda}$.

In Fig. II it is shown that $\delta$-amino-n-valeric acid was rapidly produced in the rumen from casein and acid-hydrolysed cascin in approximately equal amounts and, when the maximum concentration was reached after $\mathrm{I} h$, the equally rapid fall in concentration showed that it was readily metabolized further by the rumen microorganisms. The slow degradation of ovalbumin in the rumen was reflected in a negligible formation of $\delta$-amino-n-valeric acid. The production of large quantities of this 
intermediate when a mixture of casein and ovalbumin was added to the rumen supports the evidence which indicated that the presence of the slowly metabolized ovalbumin did not inhibit the rapid degradation of casein. $\delta$-Amino-n-valeric acid was first reported by El-Shazly (1952) to be produced in the rumen from proline by a Stickland reaction. Recently Van den Hende, Oyaert \& Bouckaert (1964) have shown that it is also an intermediate during the 'in vitro' breakdown of arginine, ornithine and citrulline by concentrated washed suspensions of rumen micro-organisms. Clarke et al. (1966) have reported that $\delta$-amino-n-valeric acid is formed in the rumen of sheep fed on a number of diets.

From the rumen fluid volume and the maximum concentration present in the rumen, the maximum amount of $\delta$-amino-n-valeric acid present in the rumen after the administration of $100 \mathrm{~g}$ casein was calculated to be $17 \cdot 2 \mathrm{mmol}$. The maximum amount which could be produced from the arginine contained in the casein is $23.6 \mathrm{mmol}$. $\delta$-Amino-n-valeric acid, however, is rapidly degraded in the rumen (Fig. II) and from the above values it is unlikely that arginine is the only amino acid residue to produce it. On the mechanisms proposed by Van den Hende et al. (1964) and ElShazly (1952), proline could also give rise to $\delta$-amino-n-valeric acid, and proline is sufficiently abundant in casein to make a considerable contribution. A preliminary experiment was carried out with the same pair of identical twin steers and under the same conditions as described for the casein experiment, in which $5 \circ \mathrm{g} \mathrm{L}$-arginine hydrochloride were added to the rumen. The rate of degradation for the single large dose of arginine was slower than for arginine contained in casein and during the $4 \mathrm{~h}$ in which the breakdown was studied citrulline and ornithine were the major products. $\delta$-Amino-n-valeric acid was produced slowly and in smaller amounts. The results, however, confirmed that the pathway proposed by Van den Hende et al. (1964) was operational in the cattle used in these experiments. In the chromatographic system used with the amino acid analyser ornithine and $\delta$-amino-n-valeric acid are eluted very close to one another. Identity was confirmed by thin-layer electrophoresis when $\delta$-amino-n-valeric acid gave a well-defined spot separate from ornithine, arginine, citrulline and $\gamma$-amino butyric acid.

\section{DISCUSSION}

Under natural conditions large quantities of soluble protein may be released into the rumen and degraded by the rumen micro-organisms in a relatively short time interval. The experimental conditions in the present work, in which a single dose of protein is added to the rumen, are therefore not abnormal. Thus, during the ingestion of herbage by cattle, Reid, Lyttleton \& Mangan (1962) showed by collection of the food bolus at the cardia and by chemical analysis of the fluid and solid fractions that large amounts of nutrients were released. Soluble protein was released from red clover leaves to the extent of $50-60 \%$ of that present, together with about $30 \%$ of the chlorophyll. Bryant (1964) has similarly shown that $3 \mathrm{I}-59 \%$ of the soluble protein of red clover was released, depending on the maturity of the herbage, and the chloroplast galactolipid similarly released was $17-29 \%$. Vetter \& Mangan (to be published) have shown similar large releases of soluble protein, potassium, chlorophyll and 
Fraction I chloroplast protein from bolus analysis with diets of red clover, white clover and lucerne. High release of soluble protein from herbage has also been shown by the intraruminal administration of penicillin to arrest fermentation (Mangan, Johns \& Bailey, 1959). A single dose of 500000 i.u. procaine penicillin ${ }_{5} \mathrm{~h}$ before feeding on red clover caused the accumulation of large amounts of soluble protein in the rumen.

In the present studies the half-life of casein in the rumen was in the range $5.6-$ $2 \mathrm{I} \cdot 5 \mathrm{~min}$ and under the conditions of the experiments a high proportion $(43 \%)$ of the protein $\mathrm{N}$ ends as excess ammonia in the rumen. This must be a minimal value because the higher level of ammonia in the rumen fluid would increase the rate of transport across the rumen epithelium. By the use of the soluble markers PEG and lithium sulphate it has been shown (unpublished results) that during a normal feeding period as much as $50 \%$ of the fluid fraction of the rumen contents leaves the rumen in about $2 \mathrm{~h}$. Thus an insoluble or slowly degraded protein in the diet could to a considerable extent pass unchanged into the lower digestive tract and thus avoid wasteful deamination in the rumen. If given in a normal diet, casein with a half-life of approximately $20 \mathrm{~min}$ is not likely to escape from the rumen before it is degraded, and McDonald \& Hall (1957) have shown that in the period up to Io $h$ after feeding with casein only 10\% was estimated to reach the duodenum intact. Although ovalbumin is a soluble protein, the present studies have shown that it is not readily degraded by rumen micro-organisms. The cyclic structure of this protein, in which there are no terminal amino or terminal carboxyl groups (Porter, 1950) would preclude degradation by proteolytic enzymes of the carboxy peptidase or the leucine amino peptidase types. With a relatively long half-life of $\mathrm{x} 80 \mathrm{~min}$, ovalbumin could pass down into the lower digestive tract to a considerable extent if it were given in a normal ration. Although ovalbumin eventually produced a high concentration of ammonia in the rumen it was a slow process, and if ovalbumin were included in a normal feed some of it would escape to the lower digestive tract before it was degraded.

Unpublished studies in vitro have shown that PEG and $\mathrm{Li}_{2} \mathrm{SO}_{4}$ added to rumen fluid in the amounts used for the measurement of rumen volumes $(2 \mathrm{~g} / 1$ and $\mathrm{I}-2 \mathrm{mEq} / \mathrm{l})$ did not inhibit fermentation. High concentrations of $\mathrm{Li}^{+}, 10-20 \mathrm{mEq} / \mathrm{l}$ however, did measurably inhibit gas production. The normal quantity of lithium sulphate did not affect the rate of breakdown of casein in the rumen of cattle nor the extent of ammonia production. The use of these markers therefore is unlikely to have affected the present studies.

Recently interest has centred on attempts to find methods by which dietary protein may be made to by-pass the rumen. Earlier work by Chalmers, Cuthbertson \& Synge (1954) showed that the abomasal infusion of casein resulted in higher $\mathrm{N}$ retention than did casein given orally or administered by a rumen fistula. Blaxter $\&$ Martin (1962), from calorimetric studies, showed that abomasal administration of casein resulted in a higher energy retention than when the protein was given by rumen fistula. Colebrook \& Reis (1969) found that when casein and other proteins were infused into the abomasum of sheep on a roughage diet there was a marked increase in wool growth and $\mathrm{N}$ retention. Ferguson, Hemsley \& Reis (1967) and Reis \& Tunks (1969) have shown that 
formaldehyde-treated casein becomes insoluble, is not degraded in the rumen, and when included in a roughage diet gave an increase in wool growth and $\mathrm{N}$ retention similar to that produced by the abomasal infusion of casein. The present results with ovalbumin suggest that the proteolytic activity in the rumen has some specificity and indicates that a study of the nature of the specificity may lead to alternative ways of making protein by-pass the rumen.

Amino acid transformations, which appeared to produce leucine, isoleucine, valine and lysine, were evident in the rumen. Histidine, which may be a limiting amino acid in milk production (Virtanen, I966), also appeared to be produced in small amounts. $\delta$-Amino-n-valeric acid produced from arginine and proline residues may be, in some circumstances, a useful indicator of the rapid degradation of protein.

I wish to express my gratitude to $\mathrm{Mr}$ P. C. Wright, Mr D. Jordan and Miss J. Willmot for their skilled assistance in this work and to $\mathrm{Mr} \mathrm{D}$. V. Barker and Mr C. Ryder (engineering) and $\mathrm{Mr}$ J. Chilvers (electronics) for the construction of the amino acid analyser. I am greatly indebted to $\mathrm{Mr} F$. A. Harrison for rumen fistulation of the cattle and for his constant help and advice concerning the animals.

\section{REFERENCES}

Abou Akkada, A. R. \& Howard, B. H. (1962). Biochem. 7. 82, 3 I 3.

Annison, E. F. (1956). Biochem. F. 64, 705.

Appleby, J. C. (1955). F. gen. Microbiol. 12, 526.

Balch, C. C. (1957). Br. 尹. Nutr. 1т, 213.

Blackburn, T. H. \& Hobson, P. N. (1962). F. gen. Microbiol. 29, 69.

Blaxter, K. L. \& Martin, A. K. (1962). Br. $\mathscr{F}$. Nutr. x6, 397.

Bryant, A. M. (1964). Proc. N.Z. Soc. Anim. Prod. 24, $5 \%$.

Bryant, M. P. \& Burkey, L. A. (1953). F. Dairy Sci. 36, 2 1 8.

Chalmers, M.I., Cuthbertson, D. P. \& Synge, R. L. M. (1954). F. agric. Sci., Camb. 44, 254.

Chibnall, A. C., Rees, M. W. \& Williams, E. F. (1943). Biochem. F. 37, 354 .

Clarke, E. M. W., Ellinger, G. M. \& Phillipson, A. T. (1966). Proc. R. Soc. B п66, 63.

Colebrook, W. F. \& Reis, P. J. ( (969). Aust. F. biol. Sci. 22, I 507.

El-Shazly, K. (1952). Biochem. F. 51, 647.

Ely, D. G., Little, C. O., Woolfolk, P. G. \& Mitchell, G. E. Jr (1967). F. Nutr. 9r, 3 I4.

Ferguson, K. A., Hemsley, J. A. \& Reis, P. J. (1967). Aust. f. Sci. 30, 215.

Fiske, C. H. \& Subbarow, Y. (1925). F. biol. Chem. 66, 375.

Gerok, W. \& Waller, H. D. (1956). Klin. Wschr. 34, 1284.

Gray, F. V., Pilgrim, A. F. \& Weller, R. A. (1958). Br. J. Nutr. 12, 413.

Hamilton, P. B. (1958). Analyt. Chem. 30, 9 I4.

Harrison, F. A. (1961). Vet. Rec. 73, 942 .

Hill, K. J. \& Mangan, J. L. (1964). Biochem. 7. 93, 39.

Hotlund, S., Quin, J. I. \& Clark, R. (1948). Onderstepoort. F. vet. Sci. Anim. Ind. 23, 395.

Hogan, J. P. \&. Weston, R. H. (1967). Aust. F. agric. Res. 18, 973.

Hume, I. D. (I970 a). Aust. F. agric. Res. 21, 297.

Hume, I. D. (1970b). Aust. F. agric. Res. 2I, 305.

Hume, I. D. \& Bird, P. R. (I970). Aust. F. agric. Res. 21, 315.

Hume, I. D., Moir, R. J. \& Somers, M. (1970). Aust. F. agric. Res. 21, 283.

Hydén, S. (1956). LantbrHögsk. Annlr 22, 139.

Kekwick, R. A. \& Cannan, R. K. (1936). Biochem. $\mathcal{F}$ 30, 227.

Lewis, D. (1955). Br. F. Nutr. 9, 215.

Lewis, D., Hill K. J. \& Annison, E. F. (1957). Biochem. F. 66, 587.

McDonald, I. W. (1948). Biochem. Y. 42, 584 .

McDonald, I. W. (1952). Biochem. F. 51, 86.

McDonald, I. W. (1954). Biochem. $\mathscr{J} .56$, т2o. 
McDonald, I. W. \& Hall, R. J. (I957). Biochem. F. 67, 400.

Mangan, J. L., Johns, A. T. \& Bailey, R. W. (I959). N.Z. fl agric. Res. 2, 342.

Mangan, J. L. \& Wright, P. C. (I968). Res. vet. Sci. 9, 366.

Moore, S. \& Stein, W. H. (I954). F. biol. Chem. 21x, 907.

Oyaert, W. \& Bouckaert, J. H. (I960). Zentbl. VetMed. 7, 929.

Pearson, R. M. \& Smith, J. A. B. (I943). Biochem. $\mathcal{F} .37$, I 53.

Pilgrim, A. F., Gray, F. V., Weller, R. A. \& Belling, C. B. (1970). Br. F. Nutr. 24, 589 .

Porter, R. R. (1950). Biochem. F. 46, 473.

Reid, C. S. W., Lyttleton, J. W. \& Mangan, J. L. (rg6z). N.Z. $\mathscr{f l}$ agric. Res. 5, 237.

Reis, P. J. \& Tunks, D. A. (r969). Aust. F. agric. Res. $20,775$.

Spackman, D. H., Stein, W. H. \& Moore, S. (1958). Analyt. Chem. 30, I I9o.

Syme, E. A. (1938), Acta Biol. exp. Vars. 12, I9.

Tristram, G. R. (I953). In The Proteins Vol. I(A), p. 2 I6 [H. Neurath and K. Bailey, editors]. New York: Academic Press.

Van den Hende, C., Oyaert, V. \& Bouckaert, I. H. (1964). Res. vet. Sci. 5, 49 r.

Virtanen, A. I. (1966). Science, N.Y. I53, 160.

Warner, A. C. 1. (1956). F. gen. Microbiol. 14, 749.

Weller, R. A., Gray, F. V. \& Pilgrim, A. F. (1958). Br. F. Nutr. 12, 42 I.

Williams, P. P., Davis, R. E., Doetsch, R. N. \& Gutierrez, J. (1961). Appl. Microbiol. 9, 405.

Wright, P. C. (1967). In Fifth Collogutum in Amino Acid Analysis p. 164. Monograph 2, Technicon International Division, Domont, France. 